\title{
Infection by Toxoplasma gondii and Leishmania spp. in humans and dogs from rural settlements in Northern Paraná State, Brazil
}

\section{Infecção por Toxoplasma gondii e Leishmania spp. em humanos e cães de assentamentos rurais no Norte do Estado do Paraná, Brasil}

\author{
Mauro de Freitas Silva Filho'; Kátia Tamekuni ${ }^{1}$; Roberta dos Santos Toledo ${ }^{1}$; \\ Renata Cristina Ferreira Dias ${ }^{1}$; Fabiana Maria Ruiz Lopis-Mori ${ }^{1}$; \\ Regina Mitsuka-Breganó2; Vanete Thomaz-Soccol3; João Luis Garcia'; \\ Roberta Lemos Freire ${ }^{4}$; Odilon Vidotto ${ }^{4}$; Italmar Teodorico Navarro ${ }^{*}$
}

\begin{abstract}
The purpose of this study was to determine the seroprevalence of antibodies against Toxoplasma gondii and Leishmania spp. in humans and dogs living in two rural settlements in northern Paraná State. An epidemiological questionnaire was applied to obtain socio-demographic information and possible associations with the infections, and the data were analyzed using EpiInfo ${ }^{\circledR}$. Blood samples were collected from 216 humans and $169 \mathrm{dogs}$, and tested by indirect immunofluorescence assay. The prevalence of toxoplasmosis in humans was 79.1\% (171/216) and in dogs was 82.2\% (139/169). Among the variables analyzed for toxoplasmosis in humans the presence of young cats in the household $(\mathrm{p}=$ 0.031 ) and higher frequency with individuals $>18$ years showed a significant association. A higher frequency of seropositive was observed in dogs aged $>1$ year. The prevalence of leishmaniasis in humans was $7.4 \%(16 / 216)$ and in dogs was $8.2 \%(14 / 169)$. The variable presence of forest less than 200 meters from the residence had a significant association among both humans and dogs. Also for dogs, there was association with the presence of organic matter (leaves) around the household. In conclusion, it can be stated that there is a high spread of $T$. gondii in both species and the occurrence of anti-Leishmania spp. antibodies in humans and dogs indicates that there is transmission of Leishmania spp. in these localities.
\end{abstract}

Key words: Toxoplasmosis, leishmaniasis, epidemiology, serology

\section{Resumo}

O objetivo deste estudo foi determinar a prevalência de anticorpos contra Toxoplasma gondii e Leishmania spp. em humanos e cães que vivem em dois assentamentos rurais no norte do Paraná. Um questionário epidemiológico foi aplicado para obter informações sociodemográficas e possíveis associações com as infecções, e os dados foram analisados pelo EpiInfo ${ }^{\circledR}$. Amostras de sangue foram coletadas de 216 pessoas e 169 cães, e testados por imunofluorescência indireta. A prevalência de toxoplasmose em humanos foi de 79,1\% (171/216) e em cães foi de $82,2 \%(139 / 169)$. Entre as variáveis analisadas para toxoplasmose em humanos a presença de gatos jovens no domicílio $(p=0,031)$ e maior

1 Post-graduate School, Animal Science, Department of Preventive Veterinary Medicine; State University of Londrina, UEL; Londrina, Paraná, Brazil.E-mail: maurobtos@hotmail.com; katiatamekuni@hotmail.com; betatoledo1@gmail.com; rcfdias14@ gmail.com; fabiuel@yahoo.com.br

2 Prof ${ }^{\mathrm{a}}$. of Department of Pathological Science, UEL, Londrina, Paraná, Brazil. E-mail: rbregano@uel.br

3 Master's Program in Biotechnology, Positivo University, Curitiba, Paraná, Brazil. E-mail: vanetesoccol@gmail.com

4 Prof. of Department of Preventive Veterinary Medicine, UEL; Londrina, Paraná, Brazil. E-mail: jlgarcia@uel.br; rlfreire@uel. br; vidotto@uel.br; italmar@uel.br

Author for corespondence 
freqüência de indivíduos $>18$ anos mostraram uma associação significativa. Uma maior frequência de soropositivos foi observada em cães com idade $>1$ ano. A prevalência de leishmaniose em seres humanos foi de 7,4\% (16/216) e em cães foi de 8,2\% (14/169). A variável presença de floresta a menos de 200 metros da residência apresentou uma associação significativa entre os seres humanos e cães. Também para os cães, houve associação com a presença de matéria orgânica (folhas) em torno da casa. Em conclusão, pode afirmar-se que existe uma grande propagação de $T$. gondii em ambas as espécies e a ocorrência de anticorpos anti-Leishmania spp. em humanos e cães, indica que há transmissão de Leishmania spp. nessas localidades.

Palavras-chave: Toxoplasmose, leishmaniose, epidemiologia, sorologia

\section{Introduction}

Toxoplasma gondii infection (NICOLLE; MANCEAUX, 1909) occurs by the ingestion of raw or undercooked meat containing tissue cysts, consumption of water and food contaminated with oocysts or by transplacental transmission of tachyzoites (TENTER; HECKEROTH; WEISS, 2000). Among the infected ones, a small percentage develop clinical signs (DUBEY et al., 2007), most serious cases, in general, are in immunocompromised individuals, ocular infection and congenital transmission (TENTER; HECKEROTH; WEISS, 2000).

In Brazil, toxoplasmosis in humans has been shown relevant in rural areas, with a higher risk of infection, in general, due to their habits and frequent contact with sources of infection (SOUZA et al., 1987). In this context, rural settlements have become areas of epidemiological importance for T. gondii, as they have a populational migration to rural area.

Clinical disease caused by T. gondii in dogs is not frequent, but two forms of the disease are reported, a multisystemic, with high mortality, particularly affecting young dogs, and another located in the central and peripheral nervous system (DUBEY; LAPPIN, 1990).

American Cutaneous Leishmaniasis (ACL) is present in all regions of Brazil and in Paraná State the disease has an endemic character, being reported in 276 of 399 cities (LIMA et al., 2002). Among the Leishmania species that cause disease in humans, Leishmania (V.) braziliensis is the most widespread in Paraná, and wild rodents indicated as probable reservoirs (BRASIL, 2007). Areas of rural settlements draw the attention, by causing environmental changes that can create risk factors in ACL focus, such as: household close to the forest, largest number of people in endemic areas, clearing of capons to build houses or even for land cultivation (LONARDONI et al., 2006).

In dogs, the reporting of infections by $L$. braziliensis is common in endemic areas of Brazil, including Northern Paraná State (DIAS et al., 1977; FALQUETO et al., 1986; MARZOCHI; BARBOSA-SANTOS, 1988, REIS et al., 2011; SESSA, FALQUETO, VAREJÃO, 1994, SILVEIRA et al., 1996a).

The aim of this study was to determine the prevalence of anti-T. gondii and anti-Leishmania spp in humans and dogs living in two rural settlements in Northern Paraná State and analyze the factors associated to these infections.

\section{Materials and Methods}

The project was approved by the Ethics Committee for Research in Human Beings ( ${ }^{\circ}$ 124/07) and Animals ( ${ }^{\circ}$ 82/2006) at the State University of Londrina.

Samples were collected from November 2006 to October 2007 in two rural settlements located in the Northern Region of Paraná State, where the main activities are beef and dairy cattle and diversified agriculture. 
The sample size calculation was obtained using EpiInfo (DEAN et al., 1994) in which was estimated four people and two dogs per lot, so in a total of 154 lots, were calculated a total population of 616 humans and 308 dogs. The minimum sample to an expected frequency of $50 \%$, with an error of $5 \%$ and a significance level of 5\% was 237 humans and 171 dogs.

The samples were analyzed by Indirect Immunofluorescence Assay (IFA) for detection of IgG anti-T. gondii and anti-Leishmania spp. The samples were considered positive for toxoplasmosis with a cutoff point of 1:16 (CAMARGO, 1973) and for leishmaniasis with a cutoff point of 1:40 (MARZOCHI; BARBOSA-SANTOS, 1988).

A questionnaire was used to analyze the epidemiological aspects, which included variables such as: age, sex, habit of eating raw meat / undercooked, presence of vegetable garden at the property, kind of work, execute activity with vegetable garden or garden, consumption of raw vegetables, origin of the vegetables, presence of dogs and cats in the household environment, have young cats, slaughter of animals at the property, presence of forest less than 200 meters from home, frequency of peridomicile cleaning, amount of organic matter in the peridomicile, kind of work of the resident, used to visit area of forest, presence of dogs in the house, and for dogs: habit of hunting, visit in forest area, habit of following the resident on daily activities, presence of characteristic lesion, among others.

The analysis of association was performed between the variables of the questionnaire and seropositivity to infection, the chi-square $\left(X^{2}\right)$ or Fisher's exact test were used, with a significance level of $5 \%$. The magnitude of the associations was verified by calculating the Odds Ratio (OR) and the significance was determined for a confidence interval of $95 \%$.

\section{Results}

Blood samples of 216 humans (103 men and 113 women) and 169 dogs (125 males and 44 females) were analyzed. The sample consisted of residents aged six to 76 years (average $=31.8$, standard deviation \pm 17.6). Among the households visited, all had running water from artesian well or mine, with most houses made of brick and sewage destined for disposal by septic tank or dry.

The prevalence of anti-T. gondii antibodies in humans was $79.1 \%(171 / 216)$ and, related to dogs, $82.2 \%$ (139/169) were reagent (Table 1). The prevalence of anti-Leishmania spp. antibodies was $7.4 \%(16 / 216)$ in humans, and 8.2\% (14/169) in dogs (Table 2).

Table 1. Distribution of anti-Toxoplasma gondii antibodies titers in serum samples of humans and canines analyzed by indirect immunofluorescence assay, in two rural settlements in the Northern of Paraná State, Brazil, 2007.

\begin{tabular}{|c|c|c|c|c|c|c|}
\hline \multirow{2}{*}{ Species } & \multirow{2}{*}{$\begin{array}{c}\% \text { of } \\
\text { positive } \\
\text { (n/total) }\end{array}$} & \multicolumn{5}{|c|}{ Titers } \\
\hline & & $\begin{array}{c}16 \\
\%(\mathrm{n} / \text { total })\end{array}$ & $\begin{array}{c}\mathbf{6 4} \\
\%(\mathrm{n} / \text { total })\end{array}$ & $\begin{array}{c}\mathbf{2 5 6} \\
\%(\mathrm{n} / \text { total })\end{array}$ & $\begin{array}{c}\mathbf{1 0 2 4} \\
\%(\mathrm{n} / \text { total })\end{array}$ & $\begin{array}{c}\mathbf{4 0 9 6} \\
\% \text { (n/total) }\end{array}$ \\
\hline Human & $\begin{array}{c}79,1 \\
(171 / 216)\end{array}$ & $\begin{array}{c}6,9 \\
(15 / 216)\end{array}$ & $\begin{array}{c}14,8 \\
(32 / 216)\end{array}$ & $\begin{array}{c}37,5 \\
(81 / 216)\end{array}$ & $\begin{array}{c}17,6 \\
(38 / 216)\end{array}$ & $\begin{array}{c}2,3 \\
(5 / 216)\end{array}$ \\
\hline Canine & $\begin{array}{c}82,2 \\
(139 / 169)\end{array}$ & $\begin{array}{c}21,3 \\
(36 / 169)\end{array}$ & $\begin{array}{c}16,5 \\
(28 / 169)\end{array}$ & $\begin{array}{c}32,0 \\
(54 / 169)\end{array}$ & $\begin{array}{c}11,2 \\
(19 / 169)\end{array}$ & $\begin{array}{c}1,2 \\
(2 / 169)\end{array}$ \\
\hline
\end{tabular}

Source: Elaboration of the authors. 
Table 2. Distribution of anti- Leishmania spp. antibodies titers in serum samples of humans and canines analyzed by indirect immunofluorescence assay, in two rural settlements in the Northern of Paraná State, Brazil, 2007.

\begin{tabular}{cccc}
\hline \multirow{2}{*}{ Species } & \%o of positive (n/total) & \multicolumn{2}{c}{ Titers } \\
\cline { 3 - 4 } & & $\mathbf{4 0}$ & $\mathbf{8 0}$ \\
& & $\%(\mathrm{n} /$ total $)$ & $\%(\mathrm{n} /$ total $)$ \\
\hline Human & $8,4(16 / 216)$ & $5,6(12 / 216)$ & $1,8(4 / 216)$ \\
Canine & $8,2(14 / 169)$ & $7,6(13 / 169)$ & $0,6(1 / 169)$ \\
\hline
\end{tabular}

Source: Elaboration of the authors.

The analysis of epidemiological data presented an association between the positivity to $T$. gondii with individuals $>18$ years $(p=0.0002)$, as well as the presence of young cats $(<1$ year) at the household $(\mathrm{p}=0.031)$. There was no significant difference between communities. There was also no significant difference between genders; however the seropositivity among women of childbearing age, 10 to 49 years (LAURENTI et al., 1990), was $80.6 \%$ (Table 3). Among the respondents, 98.6\% $(213 / 216)$ reported slaughter of animals at the property for consumption and $89.3 \%$ (42/47) who reported eating mainly chicken meat were reagent.

There was association of seropositivity of dogs with age $\geq 1$ year $(\mathrm{p}=0.011)$. There was no difference between communities. Among genders or for the others variables assessed by the epidemiological questionnaire applied, no significant associations were found (Table 4).

Regarding leishmaniasis, the analysis of epidemiological data has shown statistically significant difference for residences that were located less than 200 meters away from the forest $(p=0.005)$. There was no significant difference between the communities studied, gender, and age group analyzed or between other variables studied, with seropositivity (Table 5).

Among people evaluated, none had lesions characteristic of ACL. Five people reported having had cutaneous leishmaniasis and the treatment was effective, but they were not reagent to IFA, one of them reported to have been cured a year ago, with low serological reaction (1:20 dilution), not being considered positive. The others reported having suffered infection between five and 17 years, with a single lesion.

For dogs was significant the presence of forest less than 200 meters from the house $(p=0.036)$, habit of the owner to maintain organic matter (leaves) peridomiciliary $(\mathrm{p}=0.034)$ and the presence of characteristic skin lesions, despite the few cases, was also significant $(p=0.018)$. There was no statistically significant difference between communities, genders, age ( $\geq 1$ year or $<1$ year) or for the other variables analyzed (Table 6). 
Table 3. Analysis of variables associated to the presence of anti-Toxoplasma gondii antibodies in humans of two rural settlements in the Northern of Paraná State, Brazil, 2007.

\begin{tabular}{|c|c|c|c|}
\hline Variables & Positive samples/n (\%) & $\mathbf{p}$ & Odds Ratio (CI 95\%) \\
\hline \multicolumn{4}{|l|}{ Rural Communities } \\
\hline Iraci Salete (Alvorada do Sul) & $68 / 85(80,00)$ & 0,943 & $1,09(0,53<\mathrm{OR}<2,29)$ \\
\hline Dorcelina Folador (Arapongas) & $103 / 131(78,63)$ & & \\
\hline \multicolumn{4}{|l|}{ Age } \\
\hline$\leq 18$ years & $47 / 73(64,38)$ & $<0,001$ & $0,28(0,13<\mathrm{OR}<0,58)$ \\
\hline$>18$ years & $124 / 143(86,71)$ & & \\
\hline \multicolumn{4}{|l|}{ Gender } \\
\hline Masculine & $82 / 103(79,61)$ & 0,989 & $1,05(0,52<\mathrm{OR}<2,14)$ \\
\hline Feminine & $89 / 113(78,76)$ & & \\
\hline \multicolumn{4}{|l|}{ Women } \\
\hline$<10$ years & $4 / 8(50,00)$ & 0,117 & $\mathrm{NC}^{\mathrm{b}}$ \\
\hline$\geq 10$ to $\leq 49$ years & $71 / 88(80,68)$ & & \\
\hline$>49$ years & $14 / 17(82,35)$ & & \\
\hline \multicolumn{4}{|l|}{ Type of work } \\
\hline Farming/ Cattle breeding & $111 / 136(81,62)$ & 0,302 & $1,51(0,73<\mathrm{OR}<3,09)$ \\
\hline Domestic & $59 / 79(74,68)$ & & \\
\hline \multicolumn{4}{|l|}{ Type of meat consumed } \\
\hline Bovine & $61 / 76(80,03)$ & 0,079 & $\mathrm{NC}$ \\
\hline Pork & 68/93 $(73,19)$ & & \\
\hline Poultry & $42 / 47(89,36)$ & & \\
\hline \multicolumn{4}{|c|}{ Consumption of raw meat/ undercooked } \\
\hline Yes & $29 / 31(93,55)$ & 0,058 & $4,29(0,96<\mathrm{OR}<27,76)$ \\
\hline No & $142 / 185(76,76)$ & & \\
\hline \multicolumn{4}{|l|}{ Taste raw meat } \\
\hline Yes & $50 / 58(86,21)$ & 0,175 & $1,91(0,78<\mathrm{OR}<4,84)$ \\
\hline No & $121 / 158(76,58)$ & & \\
\hline \multicolumn{4}{|l|}{ Presence of vegetable garden } \\
\hline Yes & $115 / 145(79,31)$ & 0,917 & $1,03(0,48<\mathrm{OR}<2,19)$ \\
\hline No & $56 / 71(78,87)$ & & \\
\hline \multicolumn{4}{|c|}{ Working in vegetable garden or garden } \\
\hline Yes & $115 / 145(79,31)$ & 0,917 & $1,03(0,48<\mathrm{OR}<2,17)$ \\
\hline No & $56 / 71(78,87)$ & & \\
\hline \multicolumn{4}{|l|}{ Consumption of raw vegetables } \\
\hline Yes & $161 / 206(78,16)$ & $0,091^{\mathrm{a}}$ & - \\
\hline No & $10 / 10(100,00)$ & & \\
\hline \multicolumn{4}{|l|}{ Origin of vegetables } \\
\hline Community & $122 / 158(77,22)$ & 0,694 & $0,78(0,32<\mathrm{OR}<1,88)$ \\
\hline Outside community & $39 / 48(81,25)$ & & \\
\hline \multicolumn{4}{|l|}{ Presence of felines } \\
\hline Yes & $115 / 149(77,18)$ & 0,373 & $0,66(0,29<\mathrm{OR}<1,49)$ \\
\hline No & $56 / 67(83,58)$ & & \\
\hline \multicolumn{4}{|c|}{ Presence of young felines ( $<1$ year) } \\
\hline Yes & $45 / 51(88,24)$ & 0,031 & $3,04(1,09<\mathrm{OR}<8,95)$ \\
\hline No & $69 / 97(71,13)$ & & \\
\hline \multicolumn{4}{|l|}{ Presence of dogs } \\
\hline Yes & $134 / 173(77,46)$ & 0,302 & $0,56(0,19<\mathrm{OR}<1,52)$ \\
\hline No & $37 / 43(86,05)$ & & \\
\hline \multicolumn{4}{|l|}{ Presence of reagent dog } \\
\hline Yes & $101 / 135(74,81)$ & 0,177 & $0,45(0,14<\mathrm{OR}<1,35)$ \\
\hline No & $33 / 38(86,84)$ & & \\
\hline
\end{tabular}

a. Fisher's exact test. b. NC - Not Calculated.

Source: Elaboration of the authors. 
Table 4. Analysis of variables associated to the presence of anti-Toxoplasma gondii antibodies in dogs from two rural settlements in the Northern State of Paraná, Brazil, 2007.

\begin{tabular}{|c|c|c|c|}
\hline Variables & Positive Samples/ n (\%) & $\mathbf{p}$ & $\begin{array}{l}\text { Odds Ratio } \\
\text { (CI 95\%) }\end{array}$ \\
\hline \multicolumn{4}{|l|}{ Rural Communities } \\
\hline Iraci Salete (Alvorada do Sul) & $68 / 84(80,95)$ & 0,271 & $0,57(0,22<\mathrm{OR}<1,45)$ \\
\hline Dorcelina Folador (Arapongas) & $75 / 85(88,23)$ & & \\
\hline \multicolumn{4}{|l|}{ Age } \\
\hline$\leq 1$ year & $18 / 27(66,67))$ & 0,011 & $0,27(0,10<\mathrm{OR}<0,78)$ \\
\hline$>1$ year & $125 / 142(88,03)$ & & \\
\hline \multicolumn{4}{|l|}{ Gender } \\
\hline Male & $104 / 125(83,20)$ & 0,906 & $0,94(0,55<\mathrm{OR}<1,60)$ \\
\hline Female & $39 / 44(88,64)$ & & \\
\hline \multicolumn{4}{|l|}{ Accompany in field activities } \\
\hline Yes & $109 / 128(85,16)$ & 0,924 & $1,18(0,41<\mathrm{OR}<3,34)$ \\
\hline No & $34 / 41(82,93)$ & & \\
\hline \multicolumn{4}{|l|}{ Habit of hunting } \\
\hline Yes & $63 / 76(82,89)$ & 0,729 & $0,79(0,31<\mathrm{OR}<1,98)$ \\
\hline No & $80 / 93(86,02)$ & & \\
\hline \multicolumn{4}{|l|}{ Presence of rats } \\
\hline Yes & $89 / 106(83,96)$ & 0,932 & $0,87(0,33<\mathrm{OR}<2,28)$ \\
\hline No & $54 / 63(85,71)$ & & \\
\hline \multicolumn{4}{|c|}{ Offer viscera/raw meat of slaughtered animals } \\
\hline Yes & $93 / 110(84,55)$ & 0,126 & $2,11(0,83<\mathrm{OR}<5,36)$ \\
\hline No & $46 / 59(77,97)$ & & \\
\hline \multicolumn{4}{|l|}{ Observe animal eating abortion } \\
\hline Yes & $30 / 33(90,91)$ & 0,396 & $2,04(0,52<\mathrm{OR}<9,26)$ \\
\hline No & $113 / 136(83,09)$ & & \\
\hline \multicolumn{4}{|l|}{ Presence of felines } \\
\hline Yes & $109 / 126(86,51)$ & 0,356 & $1,70(0,63<\mathrm{OR}<4,54)$ \\
\hline No & $34 / 43(79,07)$ & & \\
\hline \multicolumn{4}{|l|}{ Presence of young felines (<1year) } \\
\hline Yes & $52 / 61(85,25)$ & 0,888 & $0,81(0,26<\mathrm{OR}<2,54)$ \\
\hline No & $57 / 65(87,69)$ & & \\
\hline
\end{tabular}

Source: Elaboration of the authors. 
Tabela 5. Analysis of variables associated to the presence of anti-Leishmania spp. antibodies in humans of two rural settlements in the Northern State of Paraná, Brazil, 2007.

\begin{tabular}{|c|c|c|c|}
\hline Variables & Positive Samples/n (\%) & $\mathbf{p}$ & $\begin{array}{l}\text { Odds Ratio } \\
\text { (CI 95\%) }\end{array}$ \\
\hline \multicolumn{4}{|l|}{ Rural Communities } \\
\hline Iraci Salete (Alvorada do Sul) & $5 / 85(5,88)$ & 0,671 & $0,68(0,2<\mathrm{OR}<2,25)$ \\
\hline Dorcelina Folador (Arapongas) & $11 / 131(8,40)$ & & \\
\hline \multicolumn{4}{|l|}{ Age } \\
\hline$\leq 10$ years & $3 / 26(11,53)$ & $0,646^{*}$ & $1,78(0,37<\mathrm{OR}<7,43)$ \\
\hline 11 to 76 years & $13 / 190(6,84)$ & & \\
\hline \multicolumn{4}{|l|}{ Gender } \\
\hline Masculine & $6 / 103(5,83)$ & 0,556 & $0,64(0,20<\mathrm{OR}<2,00)$ \\
\hline Feminine & $10 / 113(8,85)$ & & \\
\hline \multicolumn{4}{|c|}{ Presence of wood less than $200 \mathrm{~m}$ from the house } \\
\hline Yes & $8 / 43(18,60)$ & 0,005 & $4,71(1,48<\mathrm{OR}<15,03)$ \\
\hline No & $8 / 173(4,62)$ & & \\
\hline \multicolumn{4}{|l|}{ Frequency of yard cleaning } \\
\hline$\geq 30$ days & $4 / 25(16,00)$ & 0,180 & $2,84(0,70<\mathrm{OR}<10,75)$ \\
\hline$<30$ days & $12 / 191(6,28)$ & & \\
\hline \multicolumn{4}{|c|}{ Maintain organic matter (leaves) in the yard } \\
\hline Yes & $10 / 112(8,93)$ & 0,531 & $1,60(0,51<\mathrm{OR}<5,18)$ \\
\hline No & $6 / 104(5,77)$ & & \\
\hline \multicolumn{4}{|l|}{ Type of work } \\
\hline Farming/Animals & $10 / 155(6,45)$ & 0,571 & $0,63(0,20<\mathrm{OR}<2,07)$ \\
\hline Domestic & $6 / 61(9,84)$ & & \\
\hline \multicolumn{4}{|l|}{ Visiting wood area } \\
\hline Yes & $7 / 98(7,14)$ & 0,900 & $0,93(0,30<\mathrm{OR}<2,89)$ \\
\hline No & $9 / 118(7,63)$ & & \\
\hline \multicolumn{4}{|l|}{ Habit of fishing or swimming } \\
\hline Yes & $7 / 66(10,61)$ & 0,363 & $1,86(0,58<\mathrm{OR}<5,83)$ \\
\hline No & $9 / 150(6,00)$ & & \\
\hline \multicolumn{4}{|l|}{ Presence of dogs in the house } \\
\hline Yes & $10 / 173(5,78)$ & 0,132 & $0,38(0,12<\mathrm{OR}<1,27)$ \\
\hline No & $6 / 43(13,95)$ & & \\
\hline \multicolumn{4}{|l|}{ Presence of reagent dogs } \\
\hline Yes & $3 / 28(10,71)$ & 0,435 & $2,37(0,44<\mathrm{OR}<11,33)$ \\
\hline No & $7 / 145(4,83)$ & & \\
\hline
\end{tabular}

* Fisher exact test.

Source: Elaboration of the authors. 
Tabela 6. Analysis of variables associated to the presence of anti-Leishmania spp. Antibodies in dogs of two rural settlements in the Northern State of Paraná, Brazil, 2007.

\begin{tabular}{|c|c|c|c|}
\hline Variables & $\begin{array}{l}\text { Positive Samples/n } \\
(\%)\end{array}$ & $\mathbf{p}$ & $\begin{array}{l}\text { Odds Ratio } \\
\text { (CI 95\%) }\end{array}$ \\
\hline \multicolumn{4}{|l|}{ Rural Communities } \\
\hline Iraci Salete (Alvorada do Sul) & $5 / 84(5,95)$ & 0,415 & $0,53(0,15<\mathrm{OR}<1,87)$ \\
\hline Dorcelina Folador (Arapongas) & $9 / 85(10,59)$ & & \\
\hline \multicolumn{4}{|l|}{ Age } \\
\hline$<1$ year & $2 / 27(7,41)$ & $0,841^{*}$ & $1,15(0,22<\mathrm{OR}<7,97)$ \\
\hline$\geq 1$ year & $12 / 142(8,45)$ & & \\
\hline \multicolumn{4}{|l|}{ Gender } \\
\hline Male & $11 / 125(8,80)$ & $0,926^{*}$ & $1,32(0,32<\mathrm{OR}<6,30)$ \\
\hline Female & $3 / 44(6,82)$ & & \\
\hline \multicolumn{4}{|c|}{ Presence of wood less than $200 \mathrm{~m}$ from the house } \\
\hline Yes & $7 / 40(17,50)$ & 0,036 & $3,70(1,07<\mathrm{OR}<12,82)$ \\
\hline No & $7 / 129(5,43)$ & & \\
\hline \multicolumn{4}{|l|}{ Frequency of yard cleaning } \\
\hline$\geq 30$ days & $3 / 32(9,38)$ & 0,914 & $1,18(0,24<\mathrm{OR}<5,02)$ \\
\hline$<30$ days & $11 / 137(8,03)$ & & \\
\hline \multicolumn{4}{|c|}{ Maintain organic matter in the yard } \\
\hline Yes & $11 / 81(13,58)$ & 0,034 & $4,45(1,09<\mathrm{OR}<21,01)$ \\
\hline No & $3 / 88(3,41)$ & & \\
\hline \multicolumn{4}{|l|}{ Dog accompany in field activities } \\
\hline Yes & $10 / 128(7,81)$ & 0,946 & $0,78(0,21<\mathrm{OR}<3,21)$ \\
\hline Não & $4 / 41(9,76)$ & & \\
\hline \multicolumn{4}{|l|}{ Visiting wood area } \\
\hline Yes & $5 / 81(6,17)$ & 0,499 & $0,58(0,16<\mathrm{OR}<2,02)$ \\
\hline No & $9 / 88(10,23)$ & & \\
\hline \multicolumn{4}{|l|}{ Habito of hunting } \\
\hline Yes & $5 / 76(6,58)$ & 0,655 & $0,66(0,18<\mathrm{OR}<2,30)$ \\
\hline No & $9 / 93(9,68)$ & & \\
\hline \multicolumn{4}{|l|}{ Dog have short or long pelage } \\
\hline Short & $12 / 146(8,22)$ & 0,741 & $0,94(0,18<\mathrm{OR}<6,65)$ \\
\hline Long & $2 / 23(8,70)$ & & \\
\hline \multicolumn{4}{|l|}{ Presence of lesion } \\
\hline Yes & $2 / 3(66,67)$ & $0,018^{*}$ & $25,67(1,61<\mathrm{OR}<790,19)$ \\
\hline No & $12 / 166(7,23)$ & & \\
\hline \multicolumn{4}{|l|}{ Dog had lesion which is healed } \\
\hline Yes & $1 / 4(25,00)$ & 0,756 & $3,90(0,00<\mathrm{OR}<48,68)$ \\
\hline No & $13 / 165(7,88)$ & & \\
\hline
\end{tabular}

* Fisher exact test.

Source: Elaboration of the authors. 


\section{Discussion}

The Paraná State has 321 rural settlements and approximately 19.000 settled families (INCRA, 2012). The rural settlements are characterized by important environmental and population changes in relation to the region of its implantation and call attention as they can cause focus of ACL due to disordered occupation of the land and the felling of trees, whose forest is used in the construction of substandard housing, usually located at the margins of the forest (LONARDONI et al., 2006)

The prevalence of anti- $T$. gondii antibodies in the human population studied was 79.1\% (171/216). This data lines up with other studies carried out in rural areas, such as the studies performed in the macro-region of Londrina, northern of Paraná State, by Barros et al. (1993) (75\%) and Garcia and Navarro (1995) (71.3\%), and the studies carried out by Cavalcante et al. (2006) (73.3\%) in Rondônia State, and Marques (2008) (79.4\%) in Mato Grosso do Sul State. Considering the distribution of serological titers, the most frequent was 256 (48.0\%), and similar results were found by Barros et al. (1993) and Garcia et al. (1999a).

The present investigation showed that positivity for $T$. gondii is significantly higher in individuals older than 18 years $(86.7 \%)$, and there was no significant difference between genders. Similar results have been reported in the literature (CAVALCANTE et al., 2006, GARCIA et al., 1999a; SOUZA et al., 1987). Among female individuals, there was a prevalence of $50 \%$ among girls up to 10 years, and $80.7 \%$ among women of childbearing age ( $>10$ to 49 years) (LAURENTI et al., 1990), this result indicates that $4 / 5$ had contact with $T$. gondii and are practically immunized, decreasing the risk of congenital infection.

Despite the habit of eating raw or undercooked meat be of great importance for toxoplasmosis epidemiology (NAVARRO et al., 1992), this association was not significant $(\mathrm{p}=0.058)$ in this study. However, $93.5 \%$ of the individuals who reported this habit were $\operatorname{IgG}$ anti- $T$. gondii antibodies reagent. Souza et al. (1987), studied the epidemiological aspects of toxoplasmosis in school children, living in localities with urban and rural characteristics in the city of Rio de Janeiro, and showed the association of this habit to the transmission of the disease.

Contact with cats, in general, was not epidemiologically important, but the presence of young cats was important $(\mathrm{p}=0.031)$, probably because these animals are in age of greater risk of primo-infection by $T$. gondii and release oocysts into the environment (DUBEY, MILLER, FRENKEL, 1970). Souza et al. (1987) studying a rural area, found that the presence of cats in the residences influenced on the parasite transmission, in the same way, in urban areas of Minas Gerais State, Camargo, Antunes and Chiari (1995) showed higher seroprevalence in humans who had contact with cats. Dubey (1995) states that the importance of felids in the transmission of the infection lies in the environmental contamination and not due to direct contact with animals and humans.

The prevalence of toxoplasmosis in dogs of $82.2 \%$ shows a wide dissemination of the parasite in this species. Similar frequency was found by Ishizuka and Yasuda (1981) (91.0\%) in the city of São Paulo, by Freire et al. (1992) (76.0\%) in dogs attended at the Veterinary Hospital of the State University of Londrina and Garcia et al. (1999b) (84.1\%) in the city of Jaguapitã, also in the Northern Paraná State. The results were higher than the prevalence found in other studies, ranging from 12 to $63.5 \%$ (BANETH et al., 1996; BARBOSA et al., 2003; CABRAL et al., 1998; DURAN et al., 1995; GORMAN; GARCIA, LORCA, 1991; GURY DOHMEN, 1995; JACKSON; HUTCHISON; SIIM, 1987; MARQUES, 2008). The prevalence found for dogs may be related to feeding the animals with leftovers of human food, offering raw viscera of slaughtered animals and living free in the communities, making it easier to hunt, the carnivorism or even intake leftovers of abortion, although these variables were not significant in this work. 
Regarding to age group the prevalence was higher in dogs older than one year. This result was similar to findings presented by Jackson, Hutchison and Siim (1987) and Garcia et al. (1999b). There was no significant difference regarding gender $(\mathrm{p}=0.906)$, similar results are found in the literature (BANETH et al., 1996; BARBOSA et al., 2003; GARCIA et al., 1999b; MARQUES, 2008; NAVARRO, FREIRE, OGAWA, 1997).

The presence of cats or young cats was not significant for seropositivity of dogs, suggesting that the fecal-oral transmission is not the main route for infection of dogs in these communities.

Despite the presence of positive dogs or not, in the settlements, had not been significant for seropositivity of people, Ulón and Marder (1990) and Garcia et al. (1999a) showed correlations between positive titers for $T$. gondii in sera from humans and dogs, particularly in rural areas, suggesting the existence of a common route of infection for both, according to eating habits. The prevalence in dogs indicates the presence of $T$. gondii in the environment studied.

Regarding to leishmaniasis was found 7.4\% (16/216) of human's reagent to IFA for Leishmania spp. This result was lower to that observed by Gomes et al. (1992), in the Vale do Ribeira, São Paulo, where 10.2\% (27/273) were seropositive, by Silveira et al. (1996a), that found 19.9\% (136/684) of positivity in the cities of Jussara and Terra Boa, Northwest of Paraná and Nunes et al. (2006) with $13.1 \%(127 / 970)$ in the city of Varzelândia, state of Minas Gerais.

Among the seropositive there were women, children and people who reported that they performed only housework. These findings are in agreement with observations from the literature where the infection may be occurring in domiciliary and peridomiciliary area (CUNHA; LIMA; POMPEU, 2006; CORTE et al. 1996; FALQUETO et al., 1986, 1991; GOMES et al., 1992; OLIVEIRA NETO et al., 1988).
The habit of the resident to keep organic matter in peridomiciliary (leaves) was one of the factors associated with seropositivity in dogs, supporting the hypothesis of peridomestic transmission to these animals. The removal of organic matter of peridomiciliary is one of the most important measures to prevent the proliferation of vectors close to residences (BRASIL, 2008).

Despite no capture of phlebotomine sandflies was performed, studies such as by Teodoro et al. (1993), Castro et al. (2002) and Reis et al. (2011) demonstrated that in different regions of the Paraná State, the species of Lutzomyia intermedia and L. whitmani are increasing in domiciliary and peridomiciliary collecting. These insects are attracted to man, to domestic animals, such as dogs and chickens and to electricity where they find appropriate place for reproduction (organic matter) (CASTRO et al., 2002).

The present study observed lower percentage of dogs with anti-Leishmania spp. antibodies than studies from the rural region of northern Paraná, by Silveira et al. (1996b), Zanzarini et. al. (2005) and Lonardoni et al. (2006) who found, respectively, rates of $18.2 \%, 55.2 \%$ and $19 \%$ of positivity. These higher rates are justified by the fact that these authors have worked in endemic focus of ACL in humans (SILVEIRA et al., 1996b; ZANZARINI et al., 2005) or outbreak (LONARDONI et al., 2006).

Among the seropositive dogs, two had characteristic lesions of ACL, one in each settlement. The presence of dogs with positive reaction, even without lesion, was also reported by other authors (FALQUETO et al., 1986, 1991; LONARDONI et al., 2006; SILVEIRA et al., 1996b; ZANZARINI et al., 2005), in different LTA ecosystems in the country. Pirmez et al. (1988) report that lesions of leishmaniasis can show alternation of periods of cure with periods of spontaneous relapse, raising the possibility that some dogs, even infected at the time of serum collection, were not presenting characteristic lesions. 
Although there are three cases of positive serology for human and presence of reagent dog in the residence, this variable was not significant for human infection. Likewise, Zanzarini et al. (2005) did not succeed to make clear whether the dog has a role in maintaining the parasite and infection to humans or if the infection is casual. The low number found of seropositive humans and dogs might have been the cause of the non-verification of this association, as reported by Falqueto et al. (1986, 1991) and Cunha, Lima and Pompeu (2006).

Lima et al. (2002) showed that ACL in the cities of Cianorte, Japurá, Jussara and São Tomé, Paraná, are linked to areas of native remnants forests, secondary or riparian forest. Santos et al. (2005) found that $84.2 \%$ of reagent dogs had their houses less than 200 meters away from the forest in a rural community in the state of Rio de Janeiro.

The results led to the conclusion that Toxoplasma gondii is widespread in human and canine population in the communities studied and that the seropositivity for Leishmania spp. in humans and dogs, may be due to a peridomestic transmission, with strong influence by proximity to forests. The presence of young feline in the residence suggests a greater environmental contamination with oocysts, and so, a factor associated with seropositivity for toxoplasmosis in humans.

\section{Referências}

BANETH, G.; SHKAP, V.; SAVITSKY, I.; PIPANO, E. The prevalence of antibodies to Toxoplasma gondii in dogs in Israel. Israel Journal of Veterinary Medicine, v. 51, p. 31-33,1996.

BARBOSA, M. V. F.; GUIMARÃES, J. E.; ALMEIDA, M. A. O.; GONDIM, L. F. P.; REGIS, G. B. Frequência de anticorpos IgG anti-Toxoplasma gondii em soros de cães errantes da cidade de Salvador-Bahia, Brasil. Brazilian Journal of Veterinary Research and Animal Science, São Paulo, v. 40, n. 6, p. 457-465, 2003.

BARROS, M. A. I.; NAVARRO, I. T.; MARANA, E. R. M.; SHIDA, P. N. Toxoplasmose humana: inquérito sorológico em habitantes da região rural de Londrina, Paraná, Brasil. In: SEMINÁRIO BRASILEIRO DE
PARASITOLOGIA VETERINÁRIA, 8., 1993, Londrina. Anais... Londrina: Colégio Brasileiro de Parasitologia Veterinária, 1993. p. 16.

BRASIL. Ministério da Saúde. Casos de leishmaniose tegumentar americana. Brasil, grandes regiões $e$ unidades federativas. 1990 a 2006. 2008. Disponível em: $<$ http://portal.saude.gov.br/portal/arquivos/pdf/tabela lva_casos_brasil.pdf $>$. Acesso em: 07 jun. 2008.

BRASIL. Ministério da Saúde. Secretaria de Vigilância em Saúde. Manual de Vigilância da Leishmaniose Tegumentar Americana. 2. ed. Brasília: Ministério da Saúde, 2007.

CABRAL, D. D.; DE SILVA, D. A.; MIRANDA, E. O.; CUNHA, L.; FUKUSSIMA, A. C.; STUTZ, W.; BASTOS, J. E. D.; FERREIRA, F. A. Detecção de anticorpos anti-Leishmania (Viannia) braziliensis e $L$. donovani, anti-Trypanosoma cruzi e anti-Toxoplasma gondii em cães da área rural do município de Uberlândia, MG, Brasil. Veterinária Notícias, v. 4, p. 15, 1998.

CAMARGO, M. C. V.; ANTUNES, C. M.; CHIARI, C. A. Epidemiologia da infecção por Toxoplasma gondii no município de Ribeirão das Neves, MG: I - importância dos animais domésticos como fonte de infecção do $T$. gondii para o homem. Revista Sociedade Brasileira Medicina Tropical, v. 28, n. 3, p. 211-214, 1995.

CAMARGO, M. E. Introdução às tecnicas de imunofluorescência. São Paulo: Instituto de Medicina Tropical de São Paulo, 1973.

CASTRO, E. A.; THOMAZ-SOCCOL, V.; MEMBRIVE, N.; LUZ, E. Estudo das características epidemiológicas e clínicas de 332 casos de leishmaniose tegumentar notificados na região norte do Estado do Paraná de 1993 a 1998. Revista da Sociedade Brasileira de Medicina Tropical, v. 35, n. 5, p. 445-452, 2002.

CAVALCANTE, G. T.; AGUIAR, D. M.; CAMARGO, L. M. A.; LABRUNA, M. B.; ANDRADE, H. F.; MEIRELES, L. R.; DUBEY, J. P.; THULLIEZ, P.; DIAS, R. A.; GENNARI, S. M. Seroprevalence of Toxoplasma gondii antibodies in humans from rural Western Amazon, Brazil. Journal of Parasitology, Lawrence, v. 92, n. 3, p. 647-649, 2006.

CORTE, A. A.; NOZAWA, M. R.; FERREIRA, M. C.; PIGNARRI, M. G.; RANGEL, O.; LACERRA, S. S. Aspectos eco-epidemiológicos da leishmaniose tegumentar americana no Município de Campinas. Cadernos de Saúde Pública, Rio de Janeiro, v. 12, n. 4, p. 465-472, 1996.

CUNHA, J. C. L.; LIMA, J. W. O.; POMPEU, M. M. L. Transmissão domiciliar de leishmaniose tegumentar e associação entre leishmaniose humana e canina, durante 
uma epidemia na Serra de Baturité, no estado de Ceará, Brasil. Revista Brasileira de Epidemiologia, v. 9, n. 4, p. 425-435, 2006.

DEAN, A. G.; DEAN, J. A.; COULOMERIER, D.; BRENDEL, K. A.; SMITH, D. C.; BURTON, A. H.; DICKER, R. C.; SULIVAN, K. M.; FAGAN, R. F.; ARNER, T. G. Epi Info, Version 6: a word processing, data bases, and statistic program for epidemiology on microcomputers. Atlanta, Georgia, U.S.A: Center for Diseases Control and Prevention, 1994.

DIAS, M.; MAYRINK, W.; DEANE, L.; COSTA, C.; MAGAlhães, P.; MELO, M.; BATISTA, S. Epidemiologia da leishmaniose tegumentar americana. I - estudo de reservatórios em área endêmica do Estado de Minas Gerais. Revista do Instituto de Medicina Tropical de São Paulo, v. 19, p. 403-410, 1977.

DUBEY, J. P.; LAPPIN, M. Toxoplasmosis and neosporosis. In GREENE, C. E. (Ed.). Infectious diseases of the dog and cat. Philadelphia: WB Saunders, 1990. p. 818-834.

DUBEY, J. P. Duration of immunity to shedding of Toxoplama gondii oocysts by cats. The Journal of Parasitology, v. 81, n. 3, p. 410-415, 1995.

DUBEY, J. P.; CORTÉS-VECINO, J. A.; VARGASDUARTE, J. J.; SUNDAR, N.; VELMURUGAN, G. V.; BANDINI, L. M.; PÓLO, L. J.; ZAMBRANO, L.; MORA, L. E.; KWOK, O. C. H.; SMITH, T.; SU, C. Prevalence of Toxoplasma gondii in dogs from Colombia, South America and genetic characterization of $T$. gondii isolates. Veterinary Parasitology, Amsterdam, v. 145, n. 1-2, p. 45-50, 2007.

DUBEY, J. P.; MILLER, N. L.; FRENKEL, J. K. The Toxoplasma gondii oocyst from cat feces. Journal of Experimental Medicine, v. 132, n. 4, p. 636-662, 1970.

DURAN, F. P.; CABRAL, D. D.; FERREIRA, F. A.; SILVA, D. A. O.; MINEO, J. R.; SOUZA, M. A. Frequência de anticorpos anti-Toxoplasma gondii (NICOLLE E MANCEAUX, 1909) em cães clinicamente sadios da cidade de Uberlândia - MG. In : SEMINÁRIO BRASILEIRO DE PARASITOLOGIA VETERINÁRIA, 9., 1995. Campo Grande. Anais... Campo Grande: [s.n], 1995. p. 228.

FALQUETO, A.; COURA, J. R.; BARROS, G. C.; GRIMALDI-FILHO, G.; SESSA, P. A.; CARIAS, V. R. D.; JESUS, A. C.; ALENCAR, J. T. A. Participação do cão no ciclo de transmissão da leishmaniose tegumentar no Município de Viana, Estado do Espírito Santo, Brasil. Memórias do Instituto Oswaldo Cruz, Rio de Janeiro, v. 81, p. 155-163, 1986.
FALQUETO, A.; SESSA, P. A.; VAREJÃO, J. B. M.; BARROS, G. C.; MOMEN, H.; GRIMALDI JUNIOR, G. Leishmaniasis due to Leishmania braziliensis in Espírito Santo state, Brazil. Further evidence on the role of dogs as a reservoir of infection for humans. Memórias do Instituto Oswaldo Cruz, Rio de Janeiro, v. 86, p. 499500, 1991.

FREIRE, R. L.; NAVARRO, I. T.; VIDOTTO, O.; TUDURY, E. A.; VIANNA, C. C. Prevalência de anticorpos anti-Toxoplasma gondii em cães atendidos no hospital veterinário da UEL-PR. Semina: Ciências Agrárias, Londrina, v. 13, n. 1, p. 66-9, 1992.

GARCIA, J. L.; NAVARRO, I. T. Levantamento soroepidemiológico da toxoplasmose em moradores da zona rural do município de Guaraci - Paraná - Brasil. Semina: Ciências Agrárias, Londrina, v. 16, n. 1, p. 6367, 1995.

GARCIA, J. L.; NAVARRO, I. T.; OGAWA, L.; OLIVEIRA, R. C. Soroepidemiologia da toxoplasmose em gatos e cães de propriedades rurais do município de Jaguapitã, Estado do Paraná, Brasil. Ciência Rural, Santa Maria, v. 29, n. 1, p. 99-104, 1999b.

Soroprevalência do Toxoplasma gondii em suínos, bovinos, ovinos e equinos, e sua correlação com humanos, felinos e caninos, oriundos de propriedades rurais no norte do Paraná - Brasil. Ciência Rural, Santa Maria, v. 29, n. 1 p. 91-97, 1999a.

GOMES, A. C.; YAMAMOTO, Y. I.; CAPINZAIKI, A. N.; AMARAL, N. M. M.; GUIMARAES, A. J. G. Aspectos ecológicos da leishmaniose tegumentar americana: Prevalência/incidência da infecção humana nos municípios de Pedro de Toledo e Miracatu, São Paulo, Brasil. Revista do Instituto de Medicina Tropical, São Paulo, v. 34, n. 2, p. 149-58, 1992.

GORMAN, T.; GARCIA, M.; LORCA M. Infeccion por Toxoplasma gondii y Trichinella spiralis en perros de la comuna de San Bernardo, Santiago. Parasitología al Día, v. 15, p. 49-51, 1991.

GURY DOMEN, F. E. En perros y gatos de Buenos Aires. Revista de Medicina Veterinária, Buenos Aires, v. 76, n. 1, p. 65-68, 1995.

INCRA. PR: agricultores familiares e assentados fornecerão alimentos a restaurantes universitários. 2012. Disponível em: <http://www.incra.gov.br>. Acesso em: 30 out. 2012.

ISHIZUKA, M. M.; YASUDA, P. H. Incidência da infecção por Toxoplasma gondii em cães do município de São Paulo. Revista da Faculdade de Medicina Veterinária, v. 18, n. 2, p. 161-165, 1981. 
JACKSON, M. H.; HUTCHISON, W. M.; SIIM, J. C. Prevalence of Toxoplasma gondii in meat animals, cats and dogs in central Scotland. British Veterinary Journal, v. 143, n. 2, p. 159-165, 1987.

LAURENTI, R.; BUCHALLA, C. M.; LOLIO, C. A.; SANTO, A. J.; JORGE, M. H. P. M. Mortality in women of reproductive age in S. Paulo city (Brazil), 1986: I description of the project and general results. Revista de Saúde Pública, São Paulo, v. 24, n. 2, p. 128-133, 1990.

LIMA, A. P.; MINELLI, L.; COMUNELLO, E.; TEODORO, U. Distribuição da leishmaniose tegumentar por imagens de sensoriamento remoto orbital, no Estado do Paraná, Sul do Brasil. Anais Brasileiros de Dermatologia, v. 77, p. 681-92, 2002.

LONARDONI, M. V. C.; SILVEIRA, T. G. V.; ALVES, W. A.; MAIA-ELKHOURY, A. N. S.; MEMBRIVE, U. A.; MEMBRIVE, N. A.; RODRIGUES, G.; REIS N.; ZANZARINI, P. D.; ISHIKAWA, E.; TEODORO, U. Leishmaniose tegumentar americana humana e canina no Município de Mariluz, Estado do Paraná, Brasil. Cadernos de Saúde Pública, Rio de Janeiro, v. 22, n. 12, p. 2713-16, 2006.

MARQUES, J. M. Estudo da toxoplasmose em uma comunidade rural de Eldorado, MS. 2008. Dissertação (Mestrado em Ciência Animal) - Universidade Paranaense, Umuarama.

MARZOCHI, M. C. A.; BARBOSA-SANTOS, E. G. O. Evaluation of a skin test on the canine mucocutaneous leishmaniasis diagnosis. Memórias do Instituto Oswaldo Cruz, Rio de Janeiro, v. 83, p. 391-392, 1988.

NAVARRO, I. T.; VIDOTTO, O.; GIRALDI, N.; FREIRE, R. Estudo da resistência do Toxoplasma gondii ao efeito do cloreto de sódio e condimentos em linguiça frescal de suínos. Boletim Sanitário Panamericano, v. 112, p. 38-143, 1992.

NAVARRO, I. T.; FREIRE, R. L.; OGAWA, L.. Antibodies against Toxoplasma gondii in plasma of dogs seen at the UEL Veterinary Hospital. Epiodémiol Santé Animale, v. 2, n. 31-32, p. 47, 1997.

NICOLLE, C.; MANCEAUX, L. Sur une protozoaire nouveau du gondi, Toxoplasma. Archives Institute Pasteur (Tunis), v. 2, p. 216-218, 1909.

NUNES, A. G.; PAULA, E.V.; TEODORO, R.; PRATA, A.; SILVA-VERGARA, M.L. Aspectos epidemiológicos da leishmaniose tegumentar americana em Varzelândia, Minas Gerais, Brasil. Cadernos de Saúde Pública, Rio de Janeiro, v. 22, n. 6, p. 1343-1347, 2006.
OLIVEIRA-NETO, M.; PIRMEZ, C.; RANGEL, E.; SCHUBACH, A.; GRIMAKDI JUNIOR, G. An outbreak of american cutaneous leishmaniosis (Leishmania braziliensis braziliensis) in a periurban area Rio de Janeiro city, Brazil: clinical and epidemiological studies. Memórias do Instituto Oswaldo Cruz, Rio de Janeiro, v. 83, p. 427-435, 1988.

PIRMEZ, C.; COUTINHO, S. G.; MARZOCHI, M. C. A.; NUNES, M. P.; GRIMADI JUNIOR, G. Canine American cutaneous leishmaniasis: a clinical and immunological study in dogs naturally infected with $L$. braziliensis. American Journal of Tropical Medicine and Hygiene, Oxford, v. 3, p. 52-58, 1988.

REIS, H. R.; LOPES-MORI, F. M. R.; REIS, C. R.; FREIRE, R. L.; MARANA, E. R. M.; CHRYSSAFIDIS, A. L.; TEDIM, A. V.; RUFFOLO, B. B.; BUGNI, F. M.; CASTRO, E. A.; THOMAZ-SOCCOL, V.; NABUT, L. B.; NAVARRO, I. T. Soroprevalência da Leishmaniose Tegumentar Americana (LTA) canina e fauna de Flebotomíneos (Diptera: Psychodidae) em Bela Vista do Paraíso, Paraná. Semina: Ciências Agrárias, Londrina, v. 32, n. 3, p. 1083-94, 2011.

SANTOS, G. P. L.; SANAVRIA, A.; MARZOCHI, M. C. A.; SANTOS, E. G. O. B.; SILVA, V. L.; PACHECO, R. S.; MOUTA-CONFORT, M.; ESPINDOLA, C. B.; SOUZA, M. B.; PONTE, C. S.; CONCEIÇÃO, N. F.; ANDRADE, M. V. Prevalência da infecção canina em áreas endêmicas de leishmaniose tegumentar americana, do município de Paracambi, Estado do Rio de Janeiro, no período entre 1992 e 1993. Revista da Sociedade Brasileira de Medicina Tropical, Uberaba, v. 38, n. 2, p. 161-166, 2005.

SESSA, P. A.; FALQUETO, A; VAREJAO, J. B. M. Tentativa de controle da leishmaniose tegumentar americana por meio do tratamento dos cães doentes. Cadernos de Saúde Pública, Rio de Janeiro, v. 10, n. 4, p. 457-463, 1994.

SILVEIRA, T. G. V.; TEODORO, U.; LONARDONI, M. V. C.; GUILHERME, A. L. F.; TOLEDO, M. J. O.; RAMOS, M.; ARRAES, S. M. A. A.; BERTOLINI, D. A.; SPINOZA, R. P.; BARBOSA, O. C. Aspectos epidemiológicos da leishmaniose tegumentar em área endêmica do Estado do Paraná, Brasil. Cadernos de Saúde Pública, Rio de Janeiro, v. 12, n. 2, p. 141-147, 1996b.

SILVEIRA, T. G. V.; TEODORO, U.; LONARDONI, M. V. C.; TOLEDO, M. J. O.; BERTOLINI, D. A.; ARRAES, S. M. A. A.; FILHO, D. V. Investigação sorológica em cães de área endêmica de leishmaniose tegumentar, no Estado do Paraná, Sul do Brasil. Cadernos de Saúde Pública, Rio de Janeiro, v. 12, p. 89-93, 1996a. 
SOUZA, W. J. S.; COUTINHO, S. G.; LOPES, C. W. G.; SANTOS, C. S.; NEVES, N. M.; CRUZ, A. M. Epidemiological aspects of toxoplasmosis in schoolchildren residing in localities with urban or rural characteristics within the city of Rio de Janeiro, Brazil. Memórias do Instituto Oswaldo Cruz, Rio de Janeiro, v. 82, p.475-482, 1987.

TENTER, A. M.; HECKEROTH, A. R.; WEISS, L. M. Toxoplasma gondii: from animals to humans. International Journal of Parasitology, v. 30, n. 12-13, p. 1217-1258, 2000.

TEODORO, U. L. A.; SALVIA FILHO, V.; LIMA, E. M.; SPI- NOSA, R. P.; BARBOSA, O. C.; FERREIRA, M. E. M. C.; SILVEIRA, T. G. V. Flebotomíneos em área de transmissão de leishmaniose tegumentar na região norte do Estado do Paraná - Brasil: variação sazonal e atividade noturna. Revista de Saúde Pública, São Paulo, v. 27, n. 3, p. 190-194, 1993.

ULÓN, S. N.; MARDER, G. Tasas de infección toxoplásmica en el hombre y su relación com los animales domésticos en la ciudad de Corrientes. Veterinária Argentina, v. 7, n. 68, p. 518-522, 1990.

ZANZARINI, P. D.; SANTOS, D. R.; SANTOS, A. R.; OLIVEIRA, O.; POIANI, L. P.; LONARDONI, M. V. C.; TEODORO, U.; SILVEIRA, T. G. V. Leishmaniose tegumentar americana canina em municípios do norte do Estado do Paraná, Brasil. Cadernos de Saúde Pública, Rio de Janeiro, v. 21, n. 6, p. 1957-1961, 2005. 